\title{
International drivers of Brazilian agricultural cooperation in Africa in the post-2008 economic crisis
}

\author{
Agentes internacionais da cooperação agrícola brasileira \\ com a África pós-crise econômica de 2008
}

http://dx.doi.org/10.1590/0034-7329201500109

ALCIDES COSTA VAZ*

Rev. Bras. Polít. Int. 58 (1): 164-190 [2015]

\section{Introduction}

The present text analyses the major drivers of Brazilian agricultural cooperation in Africa as conceived and pursued from 2004 to 2014. Its empirical background is rooted in the political and economic changes that took place in the international system in that same period, and particularly the impacts of the 2008 economic crisis in framing Brazil's foreign policy and development assistance initiatives. In the past decade the prominence of security concerns brought about by the 2001 terrorist attacks and by the United States' responses to these gradually gave place to concerns regarding global governance challenges, not only in security but in other realms as well, making it visible that the Western powers and the international regimes they led faced difficulties in dealing with those challenges both individually and collectively. Meanwhile, China consolidated itself as a leading player in the world economy, challenging the supremacy of the United States; emerging powers, in turn, became more assertive in their intent to present themselves as necessary referents in the multilateral debate about the reconfiguration of global governance mechanisms. Development assistance emerged as a core dimension of the emerging powers' foreign policies.

In that same context, and along with other emerging powers, Brazil gained greater international visibility due to economic and social domestic achievements and to a more assertive profile sustained in its own neighborhood and on the global stage. Brazil became a leading donor among developing countries, with Africa being a priority as destination of its development assistance initiatives. Altogether, these

\footnotetext{
* International Relations Institute (IREL) of the University of Brasília (UnB), Brasília, DF, Brazil (alcidesvaz@gmail.com).
} 
developments were interpreted as constitutive dimensions of a power redistribution process that reflected the greater political and economic weight of the so-called emerging powers vis-à-vis the United States and other Western powers.

However, this still evolving process of power shift at the global level was affected, in different ways, by the 2008 economic crisis as it challenged the ability of emerging countries to play the same decisive role in shaping agendas and the course of international events into the first half of the present decade. It is a particular objective of the present text to assess how international changes derived from the 2008 economic crisis have affected Brazil's condition as an emerging power, the terms of its international insertion and, ultimately, its agricultural cooperation policy and its initiatives towards Africa in this realm.

Although the analysis addresses current international forces and developments at the systemic level, it also focuses on domestic developments, in particular those directly related to Brazilian agriculture and the policy framework of its evolving internationalization. Special attention is paid to the dual dimensions of Brazilian agricultural policy and to its projection in agricultural cooperation as pursed in Africa. Such dualism is a trait dictated by the objectives, necessities and approaches of the modern and increasingly internationalized agribusiness, ${ }^{1}$ on the one hand, and the politically valued approach to family farming in fostering food security in the developing world, on the other. ${ }^{2}$ The underlying premise is that, in the wake of the 2008 global financial crisis, the political and economic conditions under which China, Brazil, India and South Africa managed to emerge internationally have been significantly transformed, resulting in a more complex and restrictive environment for the pursuit of their global political and economic objectives.

Actually, in a context marked by a still uneven and incomplete resumption of economic growth in the United States and in Europe, as well as by the slowing down of economic growth in China and in the other emerging economies, including Brazil itself, it is not only the economic force and the ability of emerging powers to help shape the dynamics of the world economy that have been put into question, but also their political capacity to foster new parameters and mechanisms to address contemporary global governance challenges in other important areas. In other words, it is the actual ability of emerging powers to act as genuine and effective drivers of systemic changes in times of crisis that has been challenged.

In such a context, as in the case of Brazil, development assistance policies were adapted to a more restrictive international environment and to growing macroeconomic and financial constraints and political shifts domestically (Abreu 2013). As a direct consequence of widespread economic constraints, triangular

1 The term agribusiness is used here in reference to the large scale and capital intensive branch of Brazilian agriculture in order to differentiate it from family farming.

2 Even though they can be politically envisaged as complimentary dimensions of Brazilian agriculture policies, in fact they have been approached in policymaking through separate and parallel instances and instruments, even in the domain of development assistance policies. 
cooperation regained importance in the realm of development assistance policies while several bilateral initiatives in both North-South and South-South dimensions have been curtailed or frozen. However, despite the more restrictive external and domestic conditions and the emphasis now placed on trilateral initiatives, SouthSouth cooperation continues to be valued by the Brazilian government as well as by relevant domestic actors as a useful tool to foster favorable conditions for the attainment of international objectives, among them the promotion of development (Baumann 2014).

As to the impact of the financial crisis upon Brazil's economy, the analysis sustains that though the impacts were not strongly felt in more immediate terms, they have been more evident since 2011. They are associated with the difficulties Brazil has faced since then in countering economic slowdown and China's growing economic presence in Brazil's national and regional markets; in restoring domestic and external confidence in its economy; and in dealing with the outcomes of US economic and monetary policies and those arising from Europe's stagnation. Brazilian cooperation in agriculture with Africa, it is argued, has reflected this same pattern, but with different outcomes as to its two core dimensions, that is, the agribusiness led dimension and the one associated with family farming. Brazilian policy and initiatives in this domain have been conditioned and shaped by the interplay of foreign policy interests and objectives, on the one hand, and political and economic interests of the agricultural sector, as displayed internationally, on the other. However, in the past four years, they have become much more conditioned by increasing economic and budgetary constraints and by the lack of adequate institutional, legal and financial national frameworks to carry out the initiatives in course rather than by the outcomes of power shifts or other systemic processes at the international level.

The text has four sections. The first deals with the dynamics at the systemic level as dictated by the policies pursued by the developed economies and their outcomes for emerging economies and Brazil's economic performance in the past five years. It provides the background to understand the loss of impulse and credibility that the Brazilian economy has experienced. In the second section, the focus shifts to the policy framework of Brazilian agriculture in its two core dimensions, agribusiness and family farming, since policies pursued in both realms have been the primary sources of experiences and expertise for the initiatives of agricultural cooperation carried out in Africa. Having provided a broad contextual framework encompassing the external and the domestic dimensions in the first two sections, in the third one the focus shifts to the drivers of Brazilian cooperation in agriculture in Africa. This section also presents a brief review of major bilateral, multilateral and triangular arrangements encompassing those closely associated to the interests of the internationalization of Brazilian agribusiness as well as the ones focusing on agricultural development through family farming. This section lays the ground for the analysis of recent developments in major multilateral arenas 
and the prospects for Brazilian cooperation in agriculture with Africa, which is carried out in the fourth and last section.

\section{The international economic crisis and its impacts on power redistribution dynamics and on Brazil's international rise}

In order to assess the impacts of the 2008 crisis on Brazil's intents to rise as a global actor, it is necessary to provide an account of those impacts on the Brazilian economy, as it has been widely recognized that robust and sustained economic performance is a core requisite for countries willing to change their place in the international status quo and to achieve international acknowledgement and influence. Therefore, this section provides a brief account of such impacts in order to contextualize and exemplify how recent international economic trends helped raise uncertainties about Brazil's prospects as a global actor.

Six years after the outbreak of the most severe economic crisis the world has experienced since 1929, it is possible to assess its outcomes in relation to what had been conveyed by many politicians and intellectuals as a power transition process which was in course in the second decade of the post-Cold War era. Such power transition encompasses three major interlinked dynamics. The first is associated with the fate of US hegemony and with the constraints that major Western powers have faced in shaping - either individually or collectively - the power structures and the normative underpinnings of the post-Cold War order. The second is the rise of China, India, Brazil, South Africa and, ultimately, Russia, and the groupings they comprise or take part in, namely the BRICS and the G-20, as important political and economic referents in framing the debate on global governance challenges. The third is the crisis that multilateralism has been going through since the late 1990s, both as an international institution and as a major framework for the political debate at the global level.

These three elements provide the underpinnings of what could be conveyed as a power transition process in which the aspirations of emerging powers could be managed and ultimately accommodated at acceptable political costs as long as essential Western security interests were not at stake. In such a context, the rise of countries like China, India and Brazil was directly associated not only with their respective economic status but also their ability to exploit political convergences to capitalize political, strategic and economic interests pursued individually or, in some cases, collectively, and to yield greater influence in different multilateral organizations to promote the interests of the Global South. Brazil, particularly under President Lula da Silva, was particularly active in fostering initiatives to enhance its own international profile by partnering with other emerging powers to frame the debate on global governance and by linking such partnerships to the needs, concerns and interests of the Global South at large. In this endeavor, South-South relations-encompassing political dialogue, increasing trade and 
capital flows and development assistance-thus emerged as a core dimension of Brazil's international strategy and provided opportunities to enlarge the scope of its relations with other emerging powers as well as with some key partners in the developing world.

However, the sustainability of such approach to its international challenges relied significantly on Brazil's positive image, deriving largely from its economic performance domestically and externally and from its ability to commit economic, human, material and technical resources in a commensurate way to meet the challenges it is expected to address through development assistance. It is therefore necessary to provide a brief account of Brazil's economic performance in the post-2008 crisis to assess the extent to which such performance has affected its international actions and those carried out in development assistance.

Brazil's economic performance after the 2008 financial crisis has been uneven: after growing at $5.2 \%$ in 2008, Brazil's GDP dropped $0.3 \%$ in 2009 , in consonance with the immediate adverse impacts of the economic crisis on global economic growth, on investment and trade flows and on exchange rates (BCB 2015). In order to counter those impacts, the Brazilian government adopted a diversified array of economic measures in fiscal, monetary, credit and foreign exchange areas aiming at stimulating domestic consumption, protecting employment, appeasing exchange rate instability and safeguarding the Brazilian financial system. Those economic measures were successfully implemented in 2009 and led to a strong resumption of economic growth in 2010, when GDP grew at a $7.5 \%$ rate based on strong domestic consumption, abundant credit, high governmental expenditures, domestic and foreign direct investments and a gradual recovery of export flows (Ibid). Such positive economic performance seemed to confirm the idea that emerging economies, and those of the BRICS in particular, were posed to consolidate themselves as key drivers of dynamism in the global economy; domestically, that positive economic performance culminated Lula da Silva's second term and paved the way for the election of his appointed candidate, Dilma Roussef, in 2010.

However, the immediate and successful impact of those measures would be countered by the impending need to address important problems at the macroand microeconomic levels that had been evolving in previous years and that had been exacerbated by the external and domestic impacts of the 2008 financial crisis. In line with that, early in 2011, the Brazilian government implemented a strong fiscal adjustment and a severe cut of governmental expenses which had a strong adverse impact on the GDP growth rate, which dropped to $2.7 \%$ in that same year and to $0.9 \%$ in 2012 (Ibid). Economic slowdown was also followed by currency appreciation, a strong deterioration of foreign trade surpluses and inflationary pressures. The fast-paced economic slowdown was followed by a gradual loss of confidence domestically and externally in Brazil's economic foundations. Doubts rose from domestic economic agents, risk assessment agencies and foreign investors 
as to the sustainability of Brazilian economic strength. At the same time, some recent trends associated with medium-term impacts of the economic crisis also contributed to the loss of confidence in the Brazilian economy from 2012 to 2014, among them the end of the commodities boom and the decline of their prices; the slowdown of the Chinese economy; the gradual recovery of the US economy; and the change in US monetary policy that brought about the abovementioned appreciation of the Brazilian currency and the reduction of trade surpluses. In such a context, the investment rate froze at 18\% of GDP (the lowest among the BRICS countries) and productivity growth stalled at $1.3 \%$ on average. In 2014 inflation reached $6.4 \%$, trade displayed a deficit of US $\$ 3.1$ billion and the country's balance of payments registered an unprecedented US\$ 81.3 billion current account deficit (MDIC undated), thus signaling a strong deterioration of the external sector of the Brazilian economy. In sharp contrast, the unemployment rate remained at 5\%, the lowest rate in decades, while public debt dropped to $35 \%$ of GDP, international reserves hit US\$ 377 billion and Brazil remained the third major recipient of FDI. ${ }^{3}$

However, these latter positive achievements were not enough to counter the prevailing assessment that Brazil, along with its other BRICS partners, has lost political and economic momentum and international prestige, being entangled in an economic and development model that no longer provides the necessary conditions for successful adaptation and insertion into a post-crisis context in which traditional players like the United States in particular and the other OECD member countries at different levels seem to be regaining economic strength vis-àvis the emerging economies, with the exception of China. ${ }^{4}$ The positive assessments of the importance of emerging powers like China, India and Brazil in propelling world economic growth which had been widely acknowledged immediately before the 2008 crisis and even in its immediate aftermath have been critically reviewed. Positive expectations for Brazil's political and economic role both at the global and regional levels have given way to widespread domestic and external skepticism regarding not only its actual political and economic leverage and its ability to perform a leading international role in a post-crisis context, but also its own immediate prospects and the domestic underpinnings of the development strategy pursued over the past decade.

Such analysis of Brazil's current economic condition and its prospects can be framed in an overall reassessment of the importance and roles of emerging economies and the rise of South-South relations as an alternative dimension to the existing mechanisms of global governance. Undoubtedly, developing countries led by the BRICS succeeded in helping consolidate the G-20 as a mechanism for political dialogue and coordination after the outbreak of the global economic

3 OECD. FDI in Figures, April 2013. Available at: http://www.oecd.org/daf/inv/FDI\%20in\%20figures.pdf. 4 For a good critical assessment of the economic performance of the BRICS in the post-2008 years, see Sharma 2012. 
crisis, thus setting a new political reference for global economic governance in the context of an ongoing crisis of key economic multilateral bodies and regimes.

In such a context, South-South relations represent an actual, but partial component of an intended reconfiguration of global governance rather than an alternative to major economic institutions and regimes. They have benefited from converging views on the need to introduce changes in global governance mechanisms, but the convergence has also been followed by an increasing differentiation among developing countries themselves, as testified by the detachment of emerging economies from the less developed ones. Therefore, the influence of South-South relations in multilateral instances have been associated much more with the ability of emerging countries to resist proposals coming from major powers rather the ability to forge new rules and procedures to prevent the erosion of key regimes like the multilateral trade system of the World Trade Organization (WTO) or to deter even a gradual loss of relevance of the coalition mechanisms they had forged themselves. The formal announcement of the creation of a development bank and of a contingency fund by the BRICS is the only exception to the lack of action by emerging powers - China apart-at the global level in recent times.

Moreover, the expectation that South-South relations would become a driver of new parameters of development has been put into question. As expressed by Ghosh (2013),

There are fears that growing trade and investment links of the BRICS with poorer developing countries seek to exploit the natural resource base of these countries, siphoning them off in ways that are ecologically damaging, inherently unequal and of little benefit to the local people. There are concerns that cheaper exports from these semi-industrial countries undermine the competitiveness of local production in the poorer countries, thereby causing further shifts into primary commodity exporting and thereby stunting their development process.

Obviously, Ghosh's critique is strongly inspired by China's behaviour, but it is important to remember that the core of economic relations (both in trade and investment dimensions) among the BRICS countries is highly concentrated in China. Moreover, it is China's initiatives in the developing world that have attracted the attention of the international community due to the massive resources that it mobilises and the way it handles them to secure accomplishments, despite the intents of some of its BRICS partners to provide an alternative model for economic and development assistance in the realm of India-Brasil-South Africa Dialogue Forum (IBSA). In any case, Ghosh's remarks point to the fact that nationally defined interests and objectives might be the actual driving forces of those initiatives displayed through collective instances like the BRICS, thus jeopardising development opportunities they support and promote, a controversial trend that was exacerbated by the economic constraints inherited from the 2008 crisis. 
Therefore, the economic and political outcomes of the 2008 economic crisis have led, so far, to a greater fragmentation of world order. Such fragmentation is expressed in a number of factors such as: (i) the increasing reliance of the United States on Asian partnerships to counter the growing regional and global influence of China and to reassert its own hegemony; (ii) the gradual weakening of the European Union and the corresponding difficulties it faces in asserting itself as a forefront political and economic actor beyond its borders; (iii) the defiant position of Russia in the face of NATO's perceived overstretch and its intent to reposition itself as an influential power in world affairs; and (iv) the intent of the BRICS, now led by China and Russia, to counterbalance US and EU influence in major economic international regimes and institutions.

These more structural political developments are matched by some other contextual ones, among others: (i) the slow and uneven resumption of economic growth in the developed economies, with the United States recovering strength and Europe and Japan remaining stagnant; (ii) the slowdown of emerging markets, including China, but clearly expressed in the cases of Brazil and South Africa; (iii) the rise of bilateralism and WTO-plus regional and interregional trade arrangements, with the US-Asia Trans-Pacific Partnership and the eventual US-EU Transatlantic Free Trade Area currently under negotiation as its major expressions; (iv) the lack of sound policy coordination among the major economic powers; and (v) the evolving trend towards the replication and strengthening of financial arrangements to protect national economies from adverse side effects of capital flows. Against this background, only a few initiatives of coordination have advanced, like the efforts of the WTO to prevent a protectionist wave and the G-20's move to frame a debate on issues like growth resumption, convergent fiscal policies, financial regulation and measures to accelerate the pace of economic recovery worldwide. In broader terms, however, forces of fragmentation have prevailed despite US efforts to restore its economic strength, reassure and update the terms of its commitments to its major allies and reinvigorate the basis of its global hegemony.

A more fragmented order provides an unfavourable context for those political initiatives spurred by emerging countries aiming at the promotion of deep reforms of global political and economic governance mechanisms, as these tend to be either resisted or blocked by those actors whose prominence is being challenged. Moreover, getting enough support from a highly heterogeneous universe of potential partners proves to be a very hard and often unattainable political task, as illustrated by the stalemates that have prevented the multilateral debate on a number of issues on the global agenda from evolving. The deadlock of the WTO Doha Round, the lack of progress in negotiations on climate change as well as in those related to the reform of the United Nations Security Council, the non implementation of the agreed reform of IMF decision making criteria and the gradual loss of impulse of the G-20 are examples of such a trend. 
This is not an argument in favour of the demise of emerging powers in a post-2008 crisis economic order. Rather, the argument is that the conjunction of structural and contextual international processes has resulted in the emergence of an increasingly fragmented order which is far less favourable to the sort of international activism envisaged by the emerging powers about a decade ago when the first actual expressions of their willingness to work together came about under the form of ad hoc coalitions like the G-20 and institutionalised arrangements like IBSA, BASIL and, later on, the BRICS.

These initiatives were then widely acknowledged as mechanisms intended to foster the simultaneous objectives of promoting a multipolar order while strengthening multilateralism. Therefore, they would work as drivers of a more balanced power distribution not necessarily by overtly opposing the United States and its major allies directly, but by asserting their own interests and objectives as well as those of the Global South at large in an international scenario whose renewed governance they had decided to actively help forge and be a part of. Those arrangements emerged in close association with the demands of emerging powers for the reform of major political and economic global institutions in order to reflect new power realities and to foster proper conditions for the pursuit of development in a globalised yet highly asymmetric world economy. They provided room for greater political and economic exchanges among emerging countries and were thus perceived as potentially favoured drivers of the reinvigoration of South-South cooperation. Brazil itself supported and resorted to these coalitions to enhance its international influence and prestige, particularly with new partners in the developing world and in regions other than its own. However, the conditions under which all such initiatives flourished have changed significantly, thus requiring new responses by the emerging powers that have not been provided so far, allowing critical assessment of their performance and prospects to arise.

Therefore, the present international context has been largely defined by gradual, cautious and reactive responses stemming from multilateral and regional instances, national governments and corporations. It raises important constraints for countries like Brazil seeking to wield the same influence it achieved in the pre-2008 crisis and elicits the impending need to review core aspects of the development strategy it pursued over the past decade. Examples of such influence were Brazil's leading role in the 2004 WTO Cancun Ministerial Conference in bringing together developing world interests in the realm of the commercial G-20 and its active engagement in the financial G-20 in the immediate aftermath of the 2008 financial crisis.

Therefore, Brazil's ability to refute growing scepticism from financial agencies, risk analysts and domestic economic actors regarding its own weight and role as a global player relies heavily on its ability to review and reframe its international strategy in order to balance its aspirations to consolidate itself as a driver of international political and economic changes, on the one hand, and 
to find and exploit common grounds with its BRICS partners in forging the basis for sustained resumption of economic growth at rates that allow them to reposition themselves as major political and economic referents internationally, while reframing their relations with both the developed and developing world. It is against this background that we proceed to assess the performance of Brazilian agriculture in countering the adverse domestic effects of economic international crisis, its importance in the context of the Brazilian economy and its role in Brazilian international cooperation in Africa.

\section{Policy framework and responses to the challenges of the internationalisation of Brazilian agriculture in the wake of the 2008 crisis}

The performance of Brazilian agricultural exports in the post-2008 crisis: an exceptional case?

In 2008, at the onset of the world financial crisis, Brazilian agricultural exports had hit the unprecedented amount of US\$ 71.8 billion; in the following year, they decreased to US\$ 64.7 billion. Since then, however, Brazilian agricultural exports have experienced a sustained growth, reaching US\$ 76.4 billion in 2012 and US $\$ 99.9$ billion in $2013 .{ }^{5}$ Their share in Brazilian total exports has reached $41.2 \%$, a development that has been named the "primarization" of Brazilian exports, that is, the fact that the greater share of Brazilian exports are now comprised by mineral and agricultural commodities. At the same time, successive trade surpluses have been registered in the agricultural trade balance since 2011, when a US $\$ 63$ billion surplus was recorded; this reached US\$ 82.9 billion in 2013, but decreased to US\$ 69.7 billion in 2014. The strong performance of agricultural exports and the robust trade surplus in this sector contrast strongly with the performance of Brazil's total exports in that same period, which decreased from US\$256 billion to US\$ 225 billion, also running a US\$ 3.9 billion deficit in 2014 following a small trade surplus of US\$2.55 billion in 2013 (MDIC undated).

These data confirm the central importance of agriculture for the external sector of the Brazilian economy, particularly in times of slow economic growth, loss of international industrial competitiveness and accentuated deterioration of trade surpluses. They also reveal that despite the end of the boom in commodities prices, Brazilian agriculture has been much more resilient to the strongest adverse economic impacts of the 2008 global crisis than the other major segments of the Brazilian economy. Actually, agriculture has been its most dynamic sector with a huge impact on the performance of foreign trade and investment as a whole. Current forecasts indicate that despite the negative effects of the international

5 Ministério da Agricultura. Balança comercial agrícola. Available at http://www.agricultura.gov.br/internacional/ indicadores-e-estatisticas/balanca-comercial. 
crisis on Brazilian export markets for agricultural commodities, Brazil's share in world trade of some commodities is bound to increase, as is the case for soybean, beef, poultry, sugar and coffee. ${ }^{6}$ Such positive performance and prospects are key elements to explain the central role of agricultural exports not only in the context of Brazilian economic policies, but also their growing importance in the realm of foreign policy initiatives as well. It is, therefore, necessary to consider the impact of the internationalisation of Brazilian agribusiness on the sector's policy framework to analyse, subsequently, its impacts on Brazilian international cooperation policy.

\section{The policy framework for the internationalisation of Brazilian agriculture}

Brazilian agricultural policy has evolved throughout the past decade around two core dimensions. The first is represented by the fast growing and modern agribusiness which accounts for the greatest share of the production of important food commodities both for domestic and external markets like soybean (84\% of domestic production), wheat (79\%), beef $(70 \%)$, rice $(66 \%)$, maize $(64 \%)$, coffee $(62 \%)$ and poultry (50\%) (IBGE 2009). Policy initiatives in this domain have the Ministry of Agriculture, Livestock and Food Supply as their basic origin and institutional framework. The second dimension is represented by family farming, which is very relevant for the domestic market as it accounts for $33 \%$ of agricultural GDP, encompasses $84 \%$ of all rural properties, absorbs $74 \%$ of the rural labour force (Ibid) and is responsible for over $50 \%$ of the production of such basic food items as beans, milk, poultry and pork. Family farming, in turn, has the Ministry of Agrarian Development as its core political and institutional framework. At present, therefore, both segments are objects of two distinct institutional frameworks and policy planning processes, representing two distinct, albeit not exactly competing, agricultural development models.

As pursued since 2011, agricultural policy targeting the agribusiness sector has relied on four basic pillars with a primary focus on assuring proper conditions for domestic production, storage and marketing. These are the management of rural risks; the provision of technical assistance; the concession of rural credit for funding production, storage and investment; and the provision of marketing support and revenues assurance. If, on the one hand, the cornerstones of agricultural policy are not directly related to the international domain, some of its major directives, on the other, are of great relevance for the internationalisation of Brazilian agribusiness. These are to spur productivity gains through the use of adequate and modern technologies; to increase the competitiveness of the productive chain, including the segment of capital goods and agricultural processing industry; to conquer and preserve external markets for agricultural exports; and to deploy rapid and

6 http://www.bmfbovespa.com.br/pt-br/download/A-politica-agricola-na-perspectiva-de-2012-2013-CaioRocha.pdf. Access on Feb. 20, 2014. 
effective responses to unfair trade practices and anti-dumping measures affecting Brazilian agricultural exports.

In consonance with these directives, the 2013-2014 Agricultural and Cattle Plan set forth by the Ministry of Agriculture, Livestock and Food Supply envisages the increase of credit for production, the increase of storage facilities and capabilities and a significant expansion of rural insurance coverage. However, a striking feature of the Plan is the $46 \%$ increase of funds for new investments, which are expected to reach US $\$ 16.6$ billion by the end of 2014 , thus confirming agribusiness as the most dynamic sector of the Brazilian economy as a whole. The funds for the Low Carbon Agriculture Program—a program set forth in 2010 with the aim of planning and organizing the introduction of sustainable agricultural and livestock production technologies to meet the international commitment to reduce greenhouse gas emissions - shall also increase $32 \%$, as well as those to be allocated in the System of Agriculture and Livestock Defense. ${ }^{7}$

It is important to remark that, despite their domestic bias, these initiatives are intended to increase the attractiveness of Brazilian agribusiness to foreign investments and to develop greater export capabilities in order to meet the expected growth of the demand for food stemming from Asia, in particular. Forecasts made worldwide indicate that Asia will be the major source of demand for agriculture in global terms in the next ten years. Current flows already indicate that it will also be the major destination of Brazilian agricultural exports. In fact, Asia is already the region responsible for the highest rate of agricultural export growth from Brazil, with China occupying a leading position as exports destination, but with Japan and the ASEAN countries also consolidating themselves as important referent markets for Brazilian food exports.

However, a new dimension of Brazilian agribusiness has been evolving over the past decade, one that might acquire greater relevance in Brazilian policies: internationalization through the promotion of foreign investment. Traditionally the internationalization of Brazilian agribusiness has been based on the commercial dimension, encompassing dynamic expansion and the diversification of markets for its exports through intense trade promotion and commercial intelligence to identify and assess new markets and commercial opportunities, alongside greater capabilities to follow up and influence international trade negotiations. A second pillar is the attraction of foreign investments to expand domestic production capabilities, infrastructure and marketing networks and related technical and technological assets. Over the last decade the internationalization of Brazilian trademarks like JBS, Marfrig and BrFoods, currently the major transnational Brazilian companies in the sector, introduced a new dimension to the internationalization of the whole of Brazilian agribusiness, which is associated with investment partnerships and the promotion of direct investments abroad. Regardless of the relevance

7 http://www.agricultura.gov.br/desenvolvimento-sustentavel/plano-abc. Acesso em 28.02.2014. 
of such a promising trend in political and economic terms and its widespread acknowledgment as a necessary path to counter domestic and external challenges facing Brazilian agribusiness, both the number of companies operating abroad and the figures of Brazilian agribusiness investment abroad remain small. Updated figures are scarce, but a more in-depth investigation carried out by SOBEET (2009) indicated that there were only eight agribusiness companies out of a total of 211 Brazilian companies operating abroad, three of them in the food sector, three others in pulp and paper and two in the textile sector (Margarido et al. 2009). This picture helps explain the limited presence of the agribusiness sector in Brazilian development assistance policy. It is important to remark that such policy has evolved in close association with a few entities in the public sphere, like the agricultural research corporation Embrapa. Closer and stronger ties with national private agents and corporate interests are an endeavor still to be pursued with few sound antecedents.

The study also revealed that the strategies of internationalization pursued were associated primarily with the licensing of foreign retailers and distributors and the acquisition of foreign companies to produce and sell abroad. The establishment of production units through direct investments occupied a minor position in those strategies. But there are signs that this picture is currently undergoing change as leading Brazilian international agribusiness companies increase their investment in unit productions abroad, whether through partnerships, acquisitions or by settling their own units. This implies that they are also posing themselves to search for and exploit opportunities on the African continent to respond to the expected increasing demand for food on that continent and in Asia as well, as previously mentioned.

As to family farming, the second major branch of Brazil's agricultural policy, the 2013-2014 Family Farming Plan laid down by the Ministry of Agrarian Development envisaged a $16.6 \%$ increase in credit to finance the 2014 crops, reaching US $\$ 9.3$ billion—an amount four times higher than the US $\$ 2.3$ billion allocated ten years ago, when the National Family Farming Program (PRONAF) was initiated. ${ }^{8}$ Other measures to facilitate the access to and effectiveness of investments by small producers have been set forth, besides the overall increase of financial resources. However, family farming does not claim notable participation in Brazilian food exports. Basically all of small farmers' production is channeled into domestic markets, either through private and communal initiatives or through governmental programs like the Food Acquisition Program (PAA) and the National School Feeding Program (PNAE). Both programs have also become referents for Brazilian agricultural cooperation in Africa, as will be seen in the coming section.

Family farming poses real opportunities not only to adapt and respond to a fast growing domestic demand for food and food security, but also as a viable model for agricultural development in other countries, particularly in Latin

8 http://www.agroanalysis.com.br/materia_detalhe.php?idMateria=1757 
America and Africa. However, these opportunities have been overshadowed by the potential and the actual performance of agribusiness exports. Because of that, since 2005 the Ministry of Agrarian Development has worked within major Brazilian governmental agencies linked to foreign trade as well as with regional and international organizations like Mercosur and FAO to promote family farming internationally both in political and economic terms. ${ }^{9}$ Differently from the agribusiness branch, whose international appeal finds its major expression in economic terms, the international dimension of Brazilian agricultural policy associated with family farming provides good prospects both in economic and political terms. A great share of its economic potential is not directly associated with the growth of exports of agricultural commodities, but rather with the export of capital goods (tractors and farm implements in particular). Moreover, it is more amenable, as a dimension of Brazilian development assistance policy, to the intended adherence to its guiding principles and to its priorities both in terms of issues and regions to be envisaged; it also holds a very good prospect for international partnerships with a wide array of governmental and non-governmental actors. But above all, the international dimension of family farming has served the purpose of helping disseminate successful Brazilian experiences in this domain abroad, as demonstrated by the initiatives related to the School Feeding Program and the More Food International in Latin America and in Africa.

The previous analysis highlights the growing importance of international political and economic opportunities as referents for both major segments of Brazilian agriculture. Therefore, a strategic focus on such opportunities, initially associated with export markets, is now evolving toward investment opportunities abroad for Brazilian agribusiness, while family farming has been approached rather in term of its economic relevance and potential domestically and as a major political driver for disseminating Brazil's successful domestic initiatives abroad. Even though the exposure of both branches to internationally oriented policy interests and objectives is not necessarily an outcome of an articulated agricultural policy approach, it provides incentives, opportunities and demands to foster and expand agricultural international cooperation, as seen in the next section.

9 The Ministry of Agrarian Development played a decisive role in the creation of the Specialized Meeting on Family Farming of Mercosur (REAF), comprising family farmers, rural organisations and institutions of member countries. REAF is a key referent for the formulation of Mercosur's initiatives for family farming. Its initiatives in the international realm are still limited as it concentrated its efforts on laying down the basis and instruments at the national level for future regional initiatives. The establishment of common criteria to define family farming, the creation of the Mercosur Fund for Family Farming and the national registries were its most important achievements to the present. REAF is now posed to support the development of regional pilot programs and projects which represent its major priority for the next decade. With FAO the major initiative is More Food International, a program inspired by a successful Brazilian initiative that had been carried out domestically since 2004 to enhance family farming productivity, increase production and promote the sales of tractors and farm implements. More Food International, created in 2010, pursues the same objectives and targets Latin American and African countries. A more detailed account on the programme is presented in the next section. 


\section{Major political drivers and trends in Brazilian cooperation in agriculture in Africa}

Africa has become a major destination for Brazilian initiatives and resources for development assistance, and shares with South America the condition of being a political priority in this regard. ${ }^{10}$ Brazil has engaged decisively in international cooperation in Africa, having become a key donor among the developing nations, with agriculture being a leading area of Brazil's development assistance initiatives, along with health, education and professional education which altogether account for $62 \%$ of all projects carried out by Brazil in Africa. ${ }^{11}$

It would be simplistic to argue that by providing increasing development assistance to least developed countries in Africa, Brazil is somehow compensating its historically weak economic ties with them or merely responding to demands from its African partners. There has been a genuine concern by Brazil with the improvement of social and economic conditions in Africa, and through international cooperation it has been trying to share successful policy initiatives and approaches in improving agricultural productivity and this responds to a diversified array of sectoral, economic, political and diplomatic interests encompassing public and private agencies and actors (Cabral et al. 2013). The fact that Brazil has deployed diplomatic missions in 39 out of 53 African countries is a sound indication of the Brazilian political interest in that region. This is undoubtedly related to its demand for a permanent seat on the Security Council and to concerns with a broader set of issues pertaining to South-South relations, particularly across the Atlantic. ${ }^{12}$

There is also a very important economic dimension to it, especially regarding South Africa, Nigeria, Angola and Mozambique, countries where Brazilian economic presence has been growing fast through trade and investments; but again, it would be an oversimplification to connect the development assistance Brazil is providing to African countries solely with economic interests when other relevant considerations underlying Brazilian initiatives towards that continent are at stake. In the same way, it is also an oversimplification to depict Brazilian international cooperation with Africa as basically demand driven and devoid of economic interests, as stressed in diplomatic discourse.

The wide range of interests shaping Brazil's ties with African countries are reflected in the expansion of Brazilian cooperation on that continent since 2005. Between 2005 and 2012, 20 technical cooperation agreements were signed with African countries. According to official figures, the number of activities carried out in the realm of those agreements increased more than $250 \%$ as compared

10 IPEA (2014) Brazilian Cooperation for International Development 2010, p. 29.

11 ABC (2011) "Brazilian technical cooperation". Brasília: Agência Brasileira de Cooperação.

12 Sound examples of such concern are the two Africa-South America Summits in 2006 and 2009. 
to 2008, with more than 300 initiatives in 37 African countries on course since 2010 accounting for a total amount of US\$ 65 million in 2010. ${ }^{13}$ Humanitarian assistance comprises US\$ 97 million and Africa receives $7.3 \%$ of this. The greatest share of Brazilian cooperation to Africa is channeled through technical, scientific and technological cooperation projects. These sorts of projects account for $90 \%$ of all Brazilian cooperation extended to Africa, and $70 \%$ of them are destined for capacity building. As will be seen in the remaining part of this section, projects in development assistance in agriculture have this same profile.

As for bilateral initiatives, an updated account of technical assistance projects carried out under the aegis of the Brazilian Cooperation Agency demonstrates that 22 projects on agriculture are currently under way, reaching 18 African countries, ${ }^{14}$ with a primary focus on the development of human resources and technical capabilities, followed by the provision of infrastructure and technology transfer. The great majority of them are medium-term projects, that is, their implementation should last more than three years; only four of them are one or two year initiatives, but even in such cases they aim at generating important and effective technological, economic and social impacts both in the targeted sectors and at the national level.

Regarding cooperation with regional organizations, the African Union and African Development Bank have been key targets of Brazilian initiatives. In February 2011, the Brazilian government announced that it would donate US\$ 6 million from 2011 to 2013 to a fund managed by the African Development Bank to promote South-South cooperation in African countries. The fund shall finance technical assistance in sectoral studies and analysis for policymaking; development of human resources; the organization of networks and seminars to facilitate sharing of knowledge and experiences in public policies on agriculture and agribusiness; the strengthening of the private sector; clean energy and environment; governance; health; and social development. This brief account of recent Brazilian cooperation initiatives on the African continent depicts the broader context to consider the political underpinnings and current trends in agricultural cooperation in particular.

The major political drivers of Brazilian cooperation in agriculture in Africa are twofold. On the one hand, there are those closely associated with the growing influence of Brazilian agribusiness, whose economic and political leverage is also increasing as it internationalizes and poses itself to exploit investment and trade opportunities abroad and seek governmental support for that endeavor, as referred to in the previous section. Even though it is the Asian markets that are rendered relevant as promising export markets, as previously said, Africa also provides very

13 Brazilian Cooperation Agency. Brazilian technical cooperation in Africa. Brasilia: ABC, 2011, p. 8.

14 Benin, Burkina Faso, Cape Verde, Chad, Ghana, Guinea-Bissau, Kenya, Mali, Malawi, Mauritania, Mozambique, Nigeria, Senegal, South Africa, Tanzania, Togo and Zimbabwe. 
good opportunities for investments as the demand for food on the continent is also expected to increase significantly in the wake of the economic revival it has experienced over the past decade; moreover, it is also emerging as a potentially relevant platform for food exports due to the demand posed by Asian countries, China being at the forefront.

By positioning itself on the African continent, Brazilian agribusiness intends to become an active player in the development of African agriculture, and in particular in countries like Mozambique where political and cultural affinities provide a very favorable background and where geophysical, environmental and production conditions are familiar (in terms of biomes, climate, soil, water availability and access to production inputs). However, the full exploitation of such opportunities requires a massive effort, not only in significantly enhancing the local production infrastructure, but also in introducing and developing human, technical, technological and management resources, logistics and marketing structures for the provision of agricultural inputs and implements and for channeling production domestically, regionally and abroad. Brazilian ownership of expertise both in public and private enterprises and institutes in all of these areas provides great room for cooperation initiatives with African countries to evolve.

The major initiative currently under way in this perspective is the ProSavannah Project, a triangular cooperation initiative involving Brazil and Japan set forth in October 2012 which aims at the agricultural development of the Nacala Development Corridor in the savannahs of Mozambique (JICA, ABC and Government of Mozambique 2009). This region, comprising about 14 million ha in the provinces of Niassa, Nampula and Zambezia, has a very similar climate and soil characteristics to the Brazilian Cerrado where Japan played a decisive role in fostering modern soybean farming in the early 1970s. Based on that experience, both countries have been working together to apply acquired expertise in Mozambique. The project intends ultimately to foster agricultural growth in Mozambique by helping it develop improved seeds of soybean and rice, improve soil health and fund infrastructure facilities to allow production to be distributed and exported (Mourão 2011). A US\$ 1 billion fund is being set up to finance infrastructure and production initiatives. The Japan International Cooperation Agency (JICA) is the key partner from the Japanese side, while on the Brazilian side there are two major branches. The governmental branch is led by the Ministry of Foreign Affairs through the Brazilian Cooperation Agency. Acting closely with the agribusiness sector is the Getulio Vargas Foundation through GV Agro, which is working to mobilize Brazilian investors to carry out large scale projects. Due to the economic opportunities associated to the growth of agricultural production and exports, Pro-Savannah has captured the interest of Brazil's agribusiness sector, even though the project formally places a specific focus on family farming. However, this has not evolved significantly up to the present, raising deep concerns as to 
the core nature and social, economic and environmental impacts of the project for small farmers and local communities.

Even though this first dimension is primarily driven by and oriented to the economic interests of Brazilian agribusiness, it does not necessarily prevent the second major branch of Brazilian agriculture, family farming, from evolving as a space of opportunity for agricultural cooperation in Africa at large. Although certainly different and even contradictory in many senses, both models coexist in Brazil, though under different political and institutional umbrellas in the governmental realm. They also coexist, though not functionally articulated, as dimensions of Brazilian agricultural cooperation in Africa. If, as in the first case, agriculture is primarily driven by economic and market interests and opportunities as envisaged by agribusiness in the international realm, the latter is pushed by a strong willingness sponsored by the Brazilian government and by domestic political forces that support it to display its policies aiming at the development of family farming as a successful initiative with positive economic and social spill-over effects and as a core element of national and international policies for fighting hunger and poverty, a major issue of the Brazilian international agenda since Lula da Silva's government. Therefore, fostering the family farming model internationally responds to Brazil's interest in performing a leading role in framing the political debate and policies on hunger eradication and poverty elimination at the multilateral level, the Food and Agriculture Organization of the United Nations (FAO) being the major forum for this endeavor.

At present, most of Brazil's relevant international initiatives in this realm have been carried out through the Ministry of Social Development and Hunger Fighting and the Ministry of Agrarian Development in close cooperation with FAO, as seen below. Supporting the development of family farming became not just an opportune, but a necessary issue in the agenda for cooperation with African countries, as this continent is on the top of the list of regions with the worst food security in the Global Food Security Index. However, despite the diplomatic effort led by President Lula da Silva himself to frame bilateral agendas with African countries centered on the struggle against poverty and hunger as core dimensions of an economic and social development strategy, family farming development has not been as fully and effectively assimilated into bilateral agendas with African partners as expected. The reasons for this are basically associated with two major factors: first, the lack of human, financial and technical resources to support extensive bilateral commitments deriving from the active Presidential diplomacy carried out by Lula da Silva in Africa in this area; second, the complex and changing political domestic environments among African partners and their impacts on agricultural and agrarian development policies.

Therefore, the Brazilian approach to the promotion of food security through family farming in Africa has favored triangular cooperation, as already mentioned. 
The major partners are FAO, the United Kingdom and Japan. The most important expression of such broader initiatives is Purchase from Africans for Africa (PAA Africa), a program launched in February 2012 that builds on the World Food Programme's (WFP) Purchase for Progress (P4P) and that is further inspired by the Brazilian government's Food Acquisition Program (set forth in 2003) and National School Feeding Program. It pursues two main core objectives: to support innovative local initiatives of food purchase from smallholders for humanitarian food assistance, and to strengthen partnerships and strategies to fight hunger through local food purchase initiatives for food assistance. ${ }^{15}$ PAA Africa is carried out jointly by FAO, WFP, the UK Department for International Development (DFID) and Brazil. FAO is responsible for the provision of seeds and fertilizer and for boosting the capacity of small-scale farmers and farmers' associations to grow, process and sell their product. On the Brazilian side, the Ministry of Social Development of Brazil provides technical and coordination support to the learning activities of the program. The Ministry of External Relations also participates through its General Coordination for International Action Against Hunger (CGFOME) which acts as the coordinating stance of the program in the formulation of policy guidelines and in the promotion of institutional partnerships within it. PAA Africa is funded by Brazil and the United Kingdom with a total of US\$ 4.5 million and now operates experimentally in Mozambique, Senegal, Nigeria, Malawi and Ethiopia. ${ }^{16}$

Another major initiative is the project which aims at enhancing the productivity and quality of cotton production in Benin, Chad, Mali and Burkina Faso, also known as Cotton-4. Initiated in 2009, with an estimated funding of US\$ 20 million coming from the compensation paid by the US Government in implementing a WTO Dispute Settlement Body decision, this project is now starting its second phase. In its initial stage, the facilities of the Agriculture Research Center in Sotuba, Mali were reformed to host experimental crops and a modern laboratory to work on biological and genetic improvement of local cotton species. A manual for cotton cultivation and for the dissemination of experimental results was also prepared. In its second stage, Togo is expected to be incorporated, and applied joint research, exchange and broader dissemination of knowledge and improved agricultural inputs and techniques to local producers are envisaged. The Cotton- 4 project was the first developed by the Brazilian government as a

15 According to its official site, the Program focuses on three main outputs: strengthen the knowledge-sharing and lessons learned to consolidate evidence and best practices; strengthen the productive capabilities of small-scale farmers' associations selected to sell to WFP Purchase for Progress (P4P); and implement or improve local food purchase programs through direct contracts with smallholder associations for dietary diversification in school feeding programs. See paa-africa.org/about/general-information-2.

16 According to data from the Ministry of Foreign Affairs, 5,187 farmers, 125,000 students and 434 schools are currently being benefited by PAA Africa. See agenciabrasil.ebc.com.br/internacional/noticia/2014-02/faobrasil-e-referencia-mundial-no-combate-miseria. 
structuring project, that is, a project with long term and far reaching impacts not only in its own sector, but also on economic and social development conditions at large, having technological development and breakthroughs as its major underpinning. Its initial outcomes have stimulated a similar initiative to be developed with Tanzania, Kenya, Burundi and Uganda.

In the realm of multilateral initiatives, though not a strictly Brazilian one, it is worth mentioning the Agriculture Innovation Marketplace, an international endeavor comprising African, Latin American and Caribbean and Brazilian research institutions with the aim of developing cooperative projects to foster agricultural development. It has three core dimensions and objectives: (i) to stimulate and foster policy dialogue among agricultural authorities and experts to enhance mutual collaboration; (ii) to foster joint agricultural research for development projects; and (iii) to provide a forum for the discussion and sharing of outcomes of research and development projects carried out within the Marketplace itself. Brazil's participation in the Marketplace is led by Embrapa, which also has a seat in the Marketplace Steering Committee along with the Brazilian Cooperation Agency. ${ }^{17}$ The Ministry of Science, Technology and Innovation also takes part in this initiative. As a multiparty initiative, the Brazil Africa Marketplace occupies a singular position in the realm of Brazilian agricultural cooperation, but as its scope and objectives address scientific agricultural development needs and initiatives, its reach is inherently limited by the very nature of such objectives.

At the bilateral level, the major initiatives have been carried out under the umbrella of More Food International. More Food International, created in 2010, pursues the same objectives and targets in Latin American and African countries. At present, Zimbabwe, Mozambique, Senegal, Ghana and Kenya have adhered to the program. In a joint endeavor with FAO aiming at enhancing food security, it will place a particular focus on the Sahel, the poorest region of the continent. Despite being created five years ago, its achievements are relatively small as significant efforts were made to develop the domestic legal framework and the financial mechanisms for it to operate internationally. As a result of that, credits amounting to US\$ 470 million were made available to participating countries. The first export of 340 tractors was initiated in August 2014, having Zimbabwe as its destination.

17 Other international institutions with a seat in the Steering Committee are: Forum for Agricultural Research in Africa (FARA), Inter-American Institute for Cooperation on Agriculture (IICA), Bill \& Melinda Gates Foundation (BMGF), International Center for Tropical Agriculture (CIAT), DFID, FAO, Inter-American Development Bank (IDB), International Fund for Agricultural Development (IFAD) and the World Bank. For further details see africa-brazil.org. 


\section{The outcomes of developments in major multilateral arenas and groupings: prospects for Brazilian cooperation in agriculture with Africa}

Without a doubt, FAO has been the major referent for Brazilian cooperation in agriculture at large and with Africa in particular, a trend that has strengthened after the rise of José Graziano, who had led the implementation of the Zero Hunger Program during Lula da Silva's government in Brazil, as FAO's Director-General in 2009. Graziano's nomination paved the way for an intensification of cooperation initiatives with a strong accent on fighting hunger. As previously mentioned, the triangular Purchase from Africans for Africa initiative was launched in 2012; later on, in February 2013, FAO and Embrapa set up a partnership in the framework of the FAO-Brazil Regional Cooperation Program for Latin America and the Caribbean, aiming at identifying opportunities to exploit Brazilian experiences and capabilities in fighting hunger. As recently as 6 March 2014, FAO and the Community of Portuguese Speaking Countries (CPLP) launched a joint technical cooperation program to strengthen political dialogue, coordinate initiatives and develop mechanisms for enhancing the participation of political and social actors in the implementation of the CPLP's Food and Nutritional Security Strategy. Such a program provides an opportunity for Brazil to engage with its CPLP partners in agricultural cooperation. It is worth remarking that even though Portuguese speaking countries are the major beneficiaries of Brazilian development cooperation initiatives in Africa, the picture has changed dramatically when it comes to agricultural cooperation in the past three years: only two Portuguese speaking countries (Cape Verde and Mozambique) have been targeted by Brazilian agricultural cooperation, according to Brazilian Cooperation Agency data on bilateral projects.

CPLP itself has not been a privileged forum for Brazilian agricultural cooperation. The issue rose associated with the priority that Mozambique assigned to food and nutritional security in its pro-tempore presidency of that institution, thus becoming a part of the Indicative Cooperation Program 2013-2016, with two major ongoing actions: the program Promotion of Food Security in CPLP Cities Through Urban Sustainable Agriculture, now on the verge of its second phase, and the campaign Together Against Hunger: Feeding Hope. These actions, as well as CPLP itself, are limited in their scope and reach, ${ }^{18}$ and have not represented themselves as privileged channels for Brazilian agricultural cooperation. ${ }^{19}$

18 The program on food security in CPLP cities, for example, has been implemented only in two cities in Mozambique: Maputo and Nampula.

19 None of the 38 international acts celebrated among CPLP members address agricultural cooperation or related issues. Only four out of the 25 existing agreements between CPLP and other international organisations have agricultural development as an objective. From these four, three have been signed with FAO; the remaining one was signed with IFAD. For further information see cplp.org/id-391.aspx. 
Back in the realm of the United Nations agencies and bodies, a short remark on the International Fund for Agricultural Development (IFAD) is opportune. Even though most of the projects it supports are nationally conceived and developed, it has also funded some international cooperation initiatives like the establishment of a regional office of Embrapa in Ghana. Even though its actions in this domain are still limited, it may become a useful and opportune mechanism for funding some limited yet strategically important actions by Brazil in Africa.

As for the WTO, there have been no recent developments providing room or impacting Brazilian cooperation in agriculture. The last such relevant development was precisely the outcome of the Brazil-United States dispute on subsidies for cotton production, ${ }^{20}$ which had as one of its immediate outcomes the decision made by both countries in 2010 to create a fund of US $\$ 30$ million provided by the United States to support technical assistance and training activities in the cotton sector both in Brazil and in other developing nations. This fund has provided the financial resources for the implementation, from 2012 on, of the Cotton-4 Project with Benin, Chad, Mali and Burkina Faso, the first of the so-called "Development Projects" Brazil intends to pursue in Africa and other parts of the developing world. With no prospect of the Doha Round being resumed in the near future, and, therefore, no further prospects for deepening compromises in agriculture, and having overcome the cotton dispute with the United States, no incentives or developments have risen so far or seem plausible to rise in the near future that might have a meaningful impact on Brazilian agricultural cooperation in Africa.

Another instance, though limited in its scope and reach in what concerns agricultural cooperation, is the India Brazil South Africa Fund (IBSA Fund), which has destined US\$ 1.85 million from 2005 to the present to support three projects having as their ultimate objective the promotion of food security in GuineaBissau. ${ }^{21}$ These projects remain as the sole initiatives of agricultural cooperation provided by IBSA to Africa. Even though they are concentrated in one single country, they absorb $31.1 \%$ of the total financial resources of the IBSA Fund. It is also important to remark that they have no underlying commercial or other economic interests directly or indirectly attached to them. As seen in both the

20 The dispute started in 2002 with Brazil's complaint that the United States was granting subsidies for cotton production and exports, which was not in accordance with multilateral norms and agreements. After initial consultations, a panel was set up and issued a favourable response to Brazil's complaint. The US appealed, but in 2005 the original position was reaffirmed by the WTO appealing body. In April 2010, Brazil and the US signed a Memorandum of Understanding in which the US compromised with the transfer of US\$ 30 million to constitute a fund managed by a Brazilian institution to be designated by the Brazilian government to support technical assistance and training activities for the sake of supporting the development of the cotton sector in Brazil, or in the realm of cooperation initiatives in the same sector with developing countries.

21 The first of these projects, "Development of Agriculture and Small Animal Herding," was carried out from March 2005 to September 2011, and the second, "Development of Agriculture and Services to Rural Communities," from August 2009 to September 2011. The third, "Support for Lowland Rehabilitation and for Agricultural and Livestock Processing," extended from July 2011 to December 2014. 
IBSA and the BRICS cases, Brazil has favored the promotion of food security as the key driver of its agricultural cooperation initiatives towards Africa.

The BRICS, in turn, have formally assimilated agricultural cooperation in their agenda since March 2010, when their Ministers of Agriculture and Agrarian Development met for the first time, agreed to work together to design mechanisms for that purpose, and identified key issues to be addressed. ${ }^{22}$ In the next year, the ministers approved an Action Plan on Agricultural Cooperation of the BRICS Countries for the period of 2012-2016 (BRICS 2011). The Action Plan comprises five major issues. ${ }^{23}$ It is under its guidance that BRICS agricultural cooperation has evolved since then. Naturally, it casts its focus primarily on cooperation among the five countries and not on cooperation with third countries and regions. However, a specific reference to Africa was made in the Declaration in the following terms:

Agriculture is a strategic sector with a close bearing on social stability[...]. We actively support the global endeavor to combat hunger, and call on the international community to make all efforts to further enhance aid, and support the United Nations in playing a coordinating role in preventing further deterioration of the crisis, especially through the FAO's Committee on World Food Security (CSF). Meanwhile, we are committed to making best efforts to help African countries improve their food production capacity so as to enhance food security, particularly among smallholder farmers, through technical cooperation, policy dialogue, agricultural technology demonstration and transfer, personnel training, agricultural infrastructure construction and food aid, among others. (Ibid)

This piece of the Declaration is important as it not only acknowledges the utmost importance and urgency of Africans' concerns over food security, but also expresses the willingness to cooperate both multilaterally and with individual countries to enhance food security. As for Brazil, it is important to remark that it is in charge of coordinating the development of a general strategy for ensuring access to food for the most vulnerable population through, among others, the creation of a BRICS group in FAO, which shall act within WFP to coordinate initiatives to promote food security, spawn projects in the areas of food security and school meals, as well as provide incentives for purchasing local food from family farming. Although this group is not intended to act primarily towards African countries, the Ministerial Declaration makes it clear that they are acknowledged as privileged targets of BRICS agricultural cooperation. Brazil is, therefore, well positioned to

22 See http://www.brics5.co.za/about-brics/sectorial-declaration/agriculture-ministers-meeting/brics-agriculturalaction/.

23 Creation of basic agricultural information exchange system of BRICS countries; development of a general strategy for ensuring access to food for the most vulnerable population; reduction of negative impact of climate change on food security and adaptation of agriculture to climate change; and enhanced agricultural technology cooperation and innovation. 
play an active role within the BRICS and in the realm of FAO to the benefit of African countries.

The major guidelines for agricultural cooperation among the BRICS as envisaged in the 2012-2016 Action Plan address four core objectives: the creation of an agricultural information base system; the development of a general strategy for ensuring access to food for the most vulnerable population; reduction in the negative impact of climate change on food security and adaptation of agriculture to climate change; and enhancement of agricultural technology cooperation and innovation. Each of these dimensions is led by a member country and it is worth noting that Brazil leads the initiatives addressing the promotion of secure food access to vulnerable population. Here, among others, two core objectives are envisaged (BRICS 2011): to strengthen technological and industrial cooperation on livestock and fisheries, especially in the field of seawater and freshwater aquaculture to enhance the contribution of fisheries to ensuring national food security; and to promote capacity building and human resource development strategies to ensure food access for the most vulnerable population. Even though this particular instance of the BRICS comprises both agricultural and agrarian development, the latter represents, up to the present, the major referent for the implementation of the pioneering Action Plan. Another aspect that must be remarked on is that differently from IBSA, which has channeled funds to extend cooperation to third countries, the BRICS agenda is so far centered on intra-bloc initiatives. It is expected that once the newly created BRICS New Development Bank is operating, it will open a new road to agricultural cooperation by providing financial and technical support to projects in both areas.

This brief account of recent developments and outcomes in multilateral instances allows us to conclude that their importance both as forums and as instruments, although still limited, has been growing, even though they are largely concentrated in a very few institutions, FAO being at the forefront in this regard. At the same time, multilateral institutions have provided opportunities for Brazil to develop partnerships and to pursue objectives and actions on a diversified array of issues pertaining to Africa's agricultural development. Their relevance for Brazil in this regard might evolve fast as triangular cooperation also consolidates itself as an opportune resource to approach the political and economic challenges of agricultural cooperation in Africa and in other parts of the developing world.

Another noteworthy aspect is that, as clearly expressed in the IBSA and the BRICS cases, Brazil has privileged the enhancement of poor farmers' living conditions and the promotion of food security as the major drivers of its initiatives in multilateral and minilateral arrangements. This indicates that the dual dimensions of its agricultural policy are reflected in its cooperation policy through a very clear separation of the instances and countries in which the agribusiness and family farming dimensions operate. While the envisaged political objectives associated with development promotion through South-South cooperation seem to be best 
served and provided with proper instruments by groupings like IBSA and BRICS and also by initiatives like the Africa-Brazil Agricultural Innovation Marketplace, the agribusiness dimension has been pursued through either bilateral or trilateral initiatives. Such division can be associated, in turn, with a political concern in targeting specific objectives and in preventing an eventual association of these two dimensions, which could invite allegations that Brazilian development assistance policies are primarily dictated and driven by sectoral economic considerations and interests.

\section{Concluding remarks}

The previous analysis demonstrates that recent international political and economic developments have had an ambiguous impact on the course of and prospects for Brazilian agricultural cooperation in Africa. Its major international driving forces are closely associated with political and economic opportunities deriving from an expected increase in the demand for food in the coming decades, including on the African continent itself but with a major focus on Asian markets. By engaging in agricultural cooperation in Africa, Brazil therefore intends to place itself in a favorable condition to be an active player in meeting that demand in both regions, as Africa is expected to be a relevant source of food exports to Asia. On the other hand, the outcomes of the 2008 global financial crisis have led to a more restrictive international environment for the political ambitions of emerging countries like Brazil, whose overall economic performance has been severely constrained by the fast deterioration of the external sector of its economy, leading to an acute change of perceptions as to the sustainability of the development model pursued over the last decade.

In such an ambiguous context, the two major branches of Brazilian agriculture remain well poised to exploit international opportunities, though of different natures and in different realms, with Africa consolidating itself as the privileged space for such endeavors. It is also expected that development assistance will be asked to support the internationalization of Brazilian agribusiness in particular, which represents a novel challenge in approaching the necessary articulation of governmental interests and objectives, pursued domestically and externally, with those of powerful corporations in the realm of development assistance policy as a foreign policy instrument.

The force of international developments is also expressed in the assessment of outcomes in major multilateral arenas. As seen in the last section, these arenas have provided important opportunities not only to promote Brazilian objectives and interests regarding development issues at large, but also for agricultural cooperation initiatives in particular, making triangular partnerships more important while bilateral ones have stalled. Even though this conveys a pragmatic approach to opportunities, it challenges the notion that Brazil itself embraced 
and promoted of South-South cooperation as an alternative path to traditional patterns of international development assistance provided by developed countries. This, in turn, raises the issue of whether Brazil is actually fostering alternative models and practices or pragmatically exploiting opportunities within existing mechanisms. Current initiatives of agricultural cooperation in Africa have reflected such ambiguity.

\section{Bibliographic references}

Abreu, F. (2013) 'A Evolução da Cooperação Técnica Internacional no Brasil', Mural Internacional, 4(2): 3-16.

Baumann, R. (2014) Brazilian Cooperation for International Development 2010, Brasília, Brazil: Instituto de Pesquisa Econômica Aplicada / ipea.gov.br/portal/index.php?option=com_ content\&view=article\&id=21530 [accessed 3 December 2014].

BCB (2015) Indicadores Econômicos Consolidados, Brasília, Brazil: Banco Central do Brasil / bcb.gov.br/?INDECO [accessed 10 March 2015].

BRICS (2011) Action Plan 2012-2016 for Agricultural Cooperation of BRICS Countries, BRICS website / brics5.co.za/about-brics/sectorial-declaration/agriculture-ministers-meeting/ brics-agricultural-action [accessed 2 June 2014].

Cabral, L., Shankland, A., Favareto, A. and Vaz, A.C. (2013) 'Brazil-Africa Agricultural Cooperation Encounters: Drivers, Narratives and Imaginaries of Africa and Development', IDS Bulletin, 44(4): 53-68.

Ghosh, J. (2013) 'The Global Economic Chessboard and the Role of the BRICS: Brazil, Russia, India, China, South Africa', Third World Resurgence, 274 / globalresearch.ca/the-globaleconomic-chessboard-and-the-role-of-the-brics-brazil-russia-india-china-south-africa/5357502 [accessed 13 December 2014].

IBGE (2009) Censo Agropecuário 2006. Agricultura Familiar. Primeiros Resultados: Brasil, Grandes Regióes E Unidades Da Federação, Rio de Janeiro, Brazil: Instituto Brasileiro de Geografia e Estatística.

JICA, ABC and Government of Mozambique (2009) Memorandum de Entendimento Sobre a Cooperação Triangular Para o Desenvolvimento da Agricultura das Savanas Tropicais em Moçambique, Maputo, Mozambique: Japan International Cooperation Agency, Agência Brasileria de Cooperação and Government of Mozambique.

Margarido, M.A., Lima, L.A.F. and Godeguez da Silva, P. A. (2009) 'O Agronegócio nos Investimentos Externos Brasileiros’, Informaçóes Econômicas, SP, 39(9): 54.

MDIC (undated) Balança Comercial Brasileira: Dados Consolidados (Publicação), Brasília, Brazil: Ministerio do Desenvolvimento, Indústria e Comércio Exterior / desenvolvimento.gov.br//sitio/ interna/interna.php?area=5\&menu=4761 [accessed 25 January 2015].

Mourão, J. (2011) Programa de Cooperação Triangular Para O Desenvolvimento Agrícola Das Savanas Tropicais de Moçambique (ProSAVANA-JBM), Brasília, Brazil: Divisão de Cooperação Triangular e Programas Sociais, Japan International Cooperation Agency Brazil. 
Sharma, R. (2012) 'Broken BRICS: Why the Rest Stopped Rising', Foreign Affairs, 7 March 2015 / foreignaffairs.com/articles/138219/ruchir-sharma/broken-brics [accessed 25 January 2015].

SOBEET (2009) Internacionalização da Empresa Brasileira, São Paulo, Brazil: Sociedade Brasileira de Estudos de Empresas Transnacionais e da Globalização Econômica.

\author{
Submitted on March 7, 2015 \\ Accepted on May 26, 2015
}

\begin{abstract}
This text focuses on the major drivers of Brazilian agricultural cooperation in Africa as conceived and pursued from 2004 to 2014, with emphasis on the impacts of political and economic international changes that took place in that period, and particularly the impacts of the 2008 economic crisis, in framing Brazil's foreign policy and development assistance initiatives. It addresses current international forces and developments at the systemic level, but also analyses recent economic domestic developments, in particular those directly related to Brazilian agriculture and those related to the policy framework of its evolving internationalization. Special attention is paid to the dual dimensions of Brazilian agricultural policy and to its projection in agricultural cooperation as pursed in Africa.
\end{abstract}

Keywords: Africa; agricultural cooperation; Brazil; development.

\title{
Resumo
}

Este texto foca nos principais agentes da cooperação agrícola brasileira com a África como concebido e seguido de 2004 a 2014, com ênfase nos impactos das mudanças internacionais políticas e econômicas que ocorreram nesse período, e particularmente os impactos da crise econômica de 2008, enquadrando as iniciativas brasileiras de política externa e assistência ao desenvolvimento. O trabalho aborda forças internacionais e desenvolvimentos atuais em nível sistêmico, mas também analisa desenvolvimentos econômicos internos, em particular aqueles diretamente relacionados com a agricultura brasileira e os relacionados à estrutura política de sua internacionalização em desenvolvimento. Dá-se especial atenção às dimensões duais da política agrícola brasileira e sua projeção na cooperação agrícola seguida na África.

Palavras-chave: África; cooperação agrícola; Brasil; desenvolvimento. 